\title{
PENERAPAN METODE PROMETHEE DALAM SELEKSI BEASISWA MAHASISWA BERPRESTASI
}

\author{
Eka Larasati Amalia'), Dimas Wahyu Wibowo ${ }^{2)}$ \\ 1),2) Teknik Informatika, Politeknik Negeri malang \\ 1),2) eka.larasati@polinema.ac.id, dimasww@polinema.ac.id
}

\begin{abstract}
Abstrak-Penentuan penerima beasiswa yang dilakukan Politeknik Negeri Malang saat ini masih bersifat manual. Hal ini tentu memerlukan waktu yang lama dan tingkat akurasi yang rendah, karena dimungkinkan adanya pengamatan kriteria calon penerima yang terlewat. Diperlukan sebuah sistem penentuan penerimaan beasiswa yang mampu menghasilkan perangkingan yang tepat dari sebuah penilaian dengan menggunakan algoritma Promethee. Promethee (Preference Ranking Organization Method For Enrichment Evaluation) merupakan metode penentuan urutan dalam analisis multikriteria. Kriteria yang digunakan dalam proses seleksi adalah IPK, prestasi yang diperoleh, keaktifan di bidang organisasi, penghasilan kotor orangtua, kondisi keluarga, asal mahasiswa ditinjau dari letak kampus, dan mengikuti Ordik \& LDK. Dengan menggunakan metode ini menjadi suatu alat untuk dapat membantu menentukan mahasiswa yang berhak menerima beasiswa.
\end{abstract}

Kata kunci : Beasiswa, Sistem Pendukung Keputusan, Promethee.

\section{Pendahuluan}

Beasiswa adalah bantuan keuangan yang diberikan kepada perorangan untuk keberlangsungan pendidikan yang ditempuh. Tujuan diberikan beasiswa adalah memberikan penghargaan bagi mahasiswa yang telah berhasil mendapat capaian prestasi dan sebagai motivasi agar mahasiswa selalu aktif dan berprestasi. Kriteria yang digunakan dalam proses seleksi adalah IPK, prestasi yang diperoleh, keaktifan di bidang organisasi, penghasilan kotor orangtua, kondisi keluarga, asal mahasiswa ditinjau dari letak kampus, dan mengikuti Ordik \& LDK. Oleh sebab itu tidak semua mahasiswa yang mengajukan beasiswa diterima, Untuk dapat menyeleksi secara cepat dan tepat dibutuhkan sebuah sistem pengambilan keputusan.

Sistem pengambilan keputusan dalam pemilihan siswa berprestasi yang berhak menerima beasiswa menggunakan metode Promethee (Preference Ranking Organization Method For Enrichment Evaluation). Promethee merupakan metode untuk menyelesaikan suatu kasus pengambilan keputusan yang termasuk dalam kategori MCDM (Multi-criteria Decision Making) dengan prinsip outranking. Sehingga diperoleh solusi atau hasil dari beberapa alternatif untuk diambil sebuah 
keputusan. Adanya aplikasi ini diharapkan dapat membantu bagian akademik dalam menentukan mahasiswa yang tepat mendapat beasiswa.

\section{Tinjauan Pustaka}

\section{A. Promethee (Preference Ranking Organization Method for Enrichment Evaluation)}

Metode Promethee pertama kali dikembangkan oleh JP.Brans dan dipublikasikan pada tahun 1982 pada sebuah konferensi yang diorganisasikan R.Nadeau dan M.Landry di Universitas Laval, Quebec Canada. Promethee adalah salah satu metode penentuan urutan atau prioritas dalam analisis multikriteria atau MCDM (Multi Criterion Decision Making). Promethee berfungsi untuk mengolah data, baik data kuantitatif dan kualitatif sekaligus. Dimana semua data digabung menjadi satu dengan bobot penilaian yang telah diperoleh melalui penilaian atau survei.

\section{Dominasi Kriteria}

Nilai f merupakan nilai nyata suatu kriteria:

$\mathrm{f}: \mathrm{K} \rightarrow \mathfrak{R}$

Setiap alternatif $\mathrm{a} \in \mathrm{K}$, f (a) merupakan evaluasi dari alternatif tersebut untuk suatu kriteria. Pada saat dua alternatif dibandingkan, $a, b \in K$, harus dapat ditentukan perbandingan preferensinya. Penyampaian Intensitas (P) dari preferensi alternatif a terhadap alternatif $\mathrm{b}$ sedemikian rupa sehingga:

a. $\mathrm{P}(\mathrm{a}, \mathrm{b})=0$, berarti tidak ada beda (indefferent) antara a dan $b$, atau tidak ada preferensi dari a lebih baik dari $b$.

b. $\mathrm{P}(\mathrm{a}, \mathrm{b}) \approx 0$, berarti lemah preferensi dari a lebih baik dari $b$.

c. $\mathrm{P}(\mathrm{a}, \mathrm{b})=1$, kuat preferensi dari a lebih baik dari b.

d. $\mathrm{P}(\mathrm{a}, \mathrm{b}) \approx 1$, berarti mutlak preferensi dari a lebih baik dari $b$.

Dalam metode ini fungsi preferensi seringkali menghasilkan nilai fungsi yang berbeda antara dua evaluasi, sehingga :

$P(a, b)=P(f(a)-f(b))$

Dimana:

$\mathrm{P}(\mathrm{a}, \mathrm{b})$ : preferensi perbandingan alternatif $\mathrm{a}$ dan $\mathrm{b}$.

f (a) : nilai alternatif pada kritria a.

f (b) : nilai alternatif pada kritria b.

\section{Fungsi Preferensi}

Dalam Promethee terdapat enam bentuk fungsi preferensi kriteria (Kadarsah Suryadi, 2003). 


\section{a. Kriteria Biasa (Usual Criterion)}

$H(d)=\left\{\begin{array}{cc}0 & d=0 \\ 1 & |d|>0\end{array}\right.$

Keterangan :

$\mathrm{H}(\mathrm{d}) \quad$ : Fungsi selisih kriteria antar alternatif

$\mathrm{d} \quad$ : Selisih nilai kriteria $\{\mathrm{d}=\mathrm{f}(\mathrm{a})-\mathrm{f}(\mathrm{b})\}$

Fungsi H(d) untuk preferensi ini disajikan pada Gambar 1.

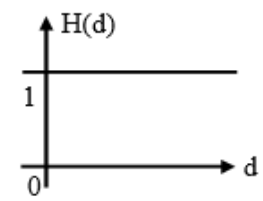

Gambar 1. Kriteria Biasa

\section{b. Kriteria Quasi (Quasi Criterion)}

$H(d)= \begin{cases}0 & |d| \leq q \\ 1 & |d|>q\end{cases}$

Keterangan :

H (d) : Fungsi selisih kriteria antar alternatif

d

: Selisih nilai kriteria $\{\mathrm{d}=\mathrm{f}(\mathrm{a})-\mathrm{f}(\mathrm{b})\}$

Parameter (q) : Harus merupakan nilai yang tetap

Fungsi H(d) untuk preferensi ini disajikan pada Gambar 2.

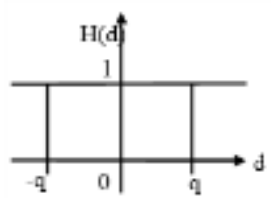

Gambar 2. Kriteria Quasi

\section{c. Kriteria Preferensi Linier}

$H(d)= \begin{cases}\frac{|d|}{p} & |d| \leq p \\ 1 & |d|>p\end{cases}$

(5)

Keterangan :

H (d) : Fungsi selisih kriteria antar alternatif

D : Selisih nilai kriteria $\{\mathrm{d}=\mathrm{f}(\mathrm{a})-\mathrm{f}(\mathrm{b})\}$

$\mathrm{p} \quad$ : Nilai kecenderungan atas 
Fungsi H (d) untuk fungsi preferensi ini disajikan pada Gambar 3.

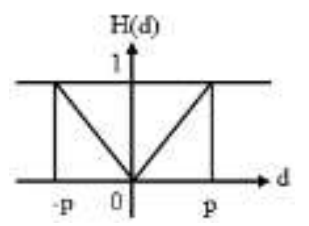

\section{Gambar 3. Kriteria Preferensi Linier}

\section{d. Kriteria Level}

$$
H(d)=\left\{\begin{array}{lr}
0 & |d| \leq q \\
\frac{1}{2} & q<|d| \leq P \\
1 & |d|>p
\end{array}\right.
$$

Keterangan:

$\mathrm{H}(\mathrm{d}) \quad$ : Fungsi selisih kriteria antar alternatif

$\mathrm{p} \quad$ : Nilai kecenderungan atas

q : Harus merupakan nilai yang tetap

Fungsi H (d) untuk fungsi preferensi ini disajikan pada Gambar 4.

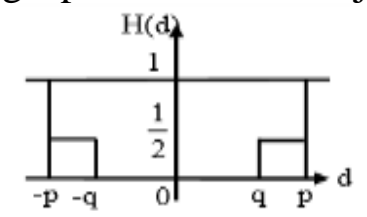

Gambar 4. Kriteria Level

\section{e. Kriteria Preferensi Linier dan area yang tidak berbeda}

$$
H(d)=\left\{\begin{array}{cc}
0 & |d| \leq q \\
\frac{|d|-q}{p-q} & q<|d| \leq p \\
1 & |d|>p
\end{array}\right.
$$

Keterangan:

H (d) : Fungsi selisih kriteria antar alternatif

d : Selisih nilai Kriteria $\{\mathrm{d}=\mathrm{f}(\mathrm{a})-\mathrm{f}(\mathrm{b})\}$

$\mathrm{p} \quad$ : Nilai kecenderungan atas

q : Harus merupakan nilai yang tetap

Fungsi $H$ (d) untuk fungsi preferensi ini disajikan pada Gambar 5.

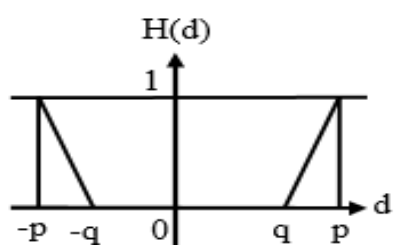

Gambar 5. Kriteria Preferensi Linier 


\section{f. Kriteria Gaussian (Gaussian Criterion) \\ $H(d)=1-\exp \left(-\frac{d^{2}}{2 \sigma^{2}}\right)$}

(8)

Fungsi H (d) untuk fungsi preferensi ini disajikan pada Gambar 6.

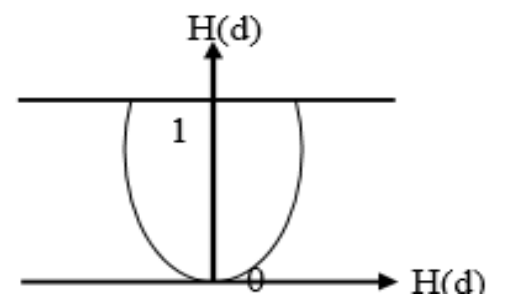

Gambar 6. Kriteria Gaussian

\section{Promethee Ranking}

Promethee rangking dibagi menjadi tiga bagian, yaitu Leaving Flow, Entering Flow, dan Net Flow.

1. Leaving Flow

$$
\varphi^{+}(a)=\frac{1}{n-1} \sum_{x \in A} \varphi(a, x)
$$

2. Entering Flow

$$
\varphi^{-}(a)=\frac{1}{n-1} \sum_{x \in A} \varphi(a, x)
$$

3. Net Flow

$$
\varphi(a)=\varphi^{+}(a)-\varphi^{-}(a)
$$

\section{Keterangan:}

1. $\varphi(a, x)=$ menunjukkan preferensi bahwa alternatif lebih baik dari alternatif $\mathrm{X}$.

2. $\varphi(a, x)=$ menunjukkan preferensi bahwa alternatif $\mathrm{x}$ lebih baik dari alternatif

3. $\varphi^{+}(a)=$ Leaving flow, digunakan untuk menentukan urutan prioritas pada proses Promethee I yang menggunakan urutan parsial.

4. $\varphi^{-}(a)=$ Entering flow, digunakan untuk menentukan urutan prioritas pada proses Promethee I yang menggunakan urutan parsial.

5. $\varphi(a)=$ Net flow, digunakan untuk menghasilkan keputusan akhir penentuan urutan dalam menyelesaikan masalah sehingga menghasilkan urutan lengkap. 


\section{Metode Penelitian}

\section{A. Desain Sistem}

\section{Analisa Kebutuhan Sistem}

Pada sistem ini, user dapat memasukan sendiri masukan data masing-masing parameter sesuai dengan range yang telah disediakan oleh sistem. Sistem akan memproses data input untuk dikelompokan sesuai fungsi keanggotaan dan rule yang telah ditentukan.

c. Kebutuhan Masukan

Kebutuhan masukan sistem terdiri dari: asal mahasiswa, nilai IPK, keaktifan di bidang organisasi, kondisi keluarga, ordik \& LDK, penghasilan kotor orangtua, prestasi yang diperoleh non akademik.

d. Kebutuhan Keluaran

Keluaran sistem berupa rekomendasi nama mahasiswa yang berhak mendapatkan beasiswa.

\section{Use Case Diagram}

Use case diagram digunakan untuk menggambarkan interaksi antara user dan sistem. Diagram use case untuk penerapan metode Promethee dalam seleksi beasiswa mahasiswa berprestasi dapat diperlihatkan dalam Gambar 7.

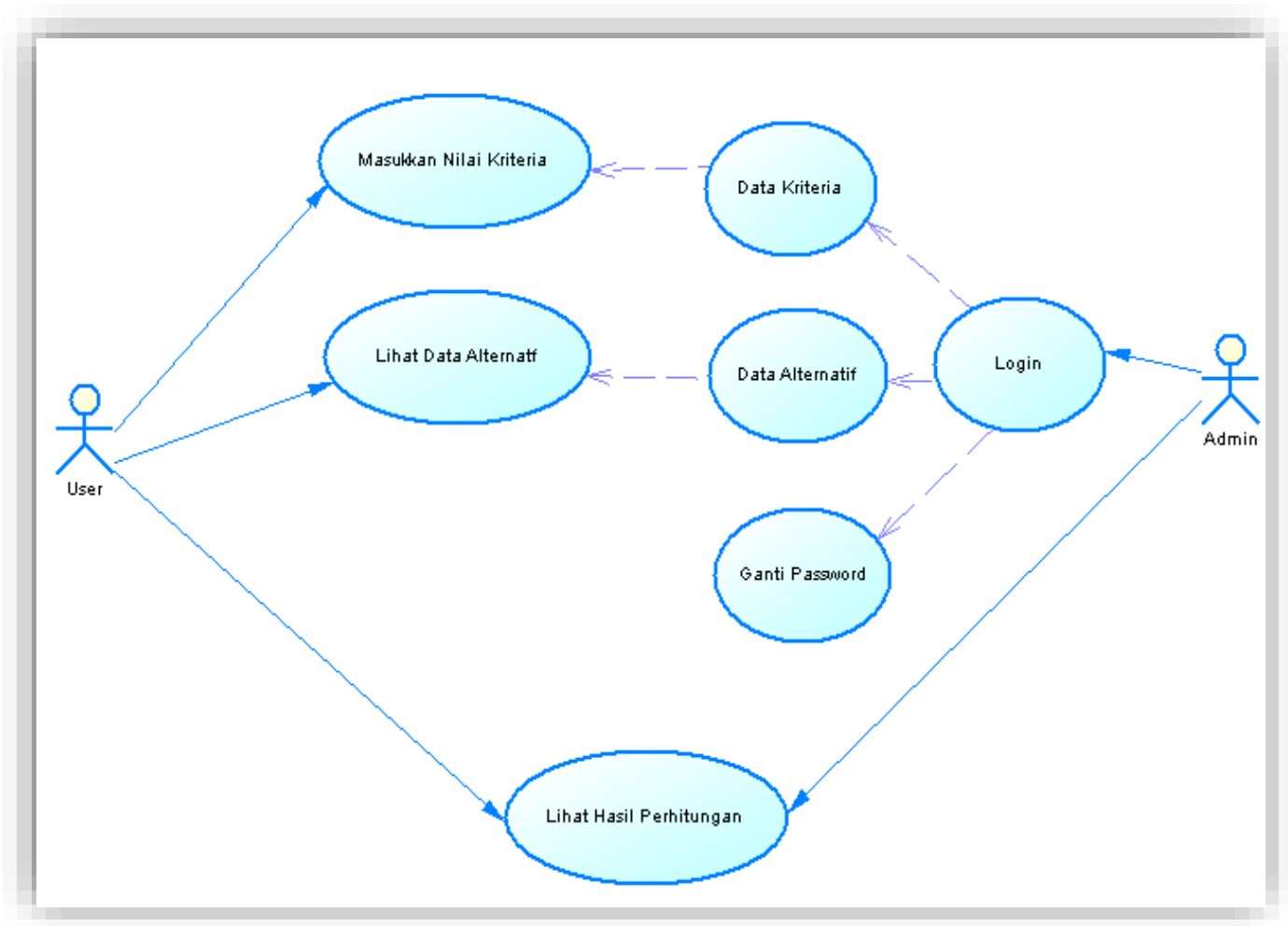

Gambar 7. Diagram Use Case

Antivirus: Jurnal Ilmiah dan Teknik Informatika, Mei 2017, Vol.11, No. 1 


\subsection{Skenario Use Case}

Tahapan-tahapan skenario use case yang sedang berjalan adalah sebagai berikut:

a. Nama use case : Masukkan Nilai Kriteria

Aktor : User

Tujuan : Memasukkan nilai kriteria yang akan digunakan dalam proses pengambilan keputusan.

Tabel 5. Skenario Use Case Masukkan Nilai Kriteria

$\frac{\text { User }}{\text { 1. Masukkan nilai kriteria }}$

2. Simpan hasil masukkan Sistem

3. Menampilkan hasil
masukkan dari user
4. Menampilkan hasil
perhitungan sementara

5. Klik tombol perhitungan sementara

"selanjutnya"

6. Menampilkan hasil perangkingan

\section{b. Nama use case : Masukkan Data Kriteria dan Alternatif}

Aktor

Tujuan
: Admin

: Memasukkan nilai kriteria dan alternatif yang akan digunakan dalam proses pengambilan keputusan

Tabel 6. Skenario Use Case Masukkan Data Kriteria \& Alternatif

\begin{tabular}{l} 
Admin \\
\hline 1. Login Admin \\
3. Masukkan data kriteria \\
4. Masukkan data alternatif \\
5. Klik tombol "simpan"
\end{tabular}

6. Menampilkan data yang telah ditambahkan

$$
\begin{aligned}
& \text { 2. Memverifikasi } \\
& \text { username \& password } \\
& \text { yang dimasukkan }
\end{aligned}
$$

4. Masukkan data alternatif

\section{Data Flow Diagram}

Data Flow Diagram menggambarkan aliran data yang terjadi di dalam sistem, sehingga dengan dibuatnya DFD ini akan terlihat arus data yang mengalir dalam sistem.

\subsection{Diagram Konteks}

Pada diagram konteks dari penerapan metode Promethee dalam seleksi beasiswa mahasiswa berprestasi masukan pada sistem tersebut serta hasil yang diperoleh user sebagai entity berbeda. Admin memberikan masukan berupa 
data kriteria dan data alternatif, kemudian sistem akan menyimpan data-data tersebut untuk diolah menggunakan metode Promethee. Pada saat user memasukkan data-data untuk diolah maka sistem akan mengolah data-data dari user berdasarkan data-data kriteria yang diinputkan oleh user. Untuk lebih detailnya dapat dilihat pada Gambar 8

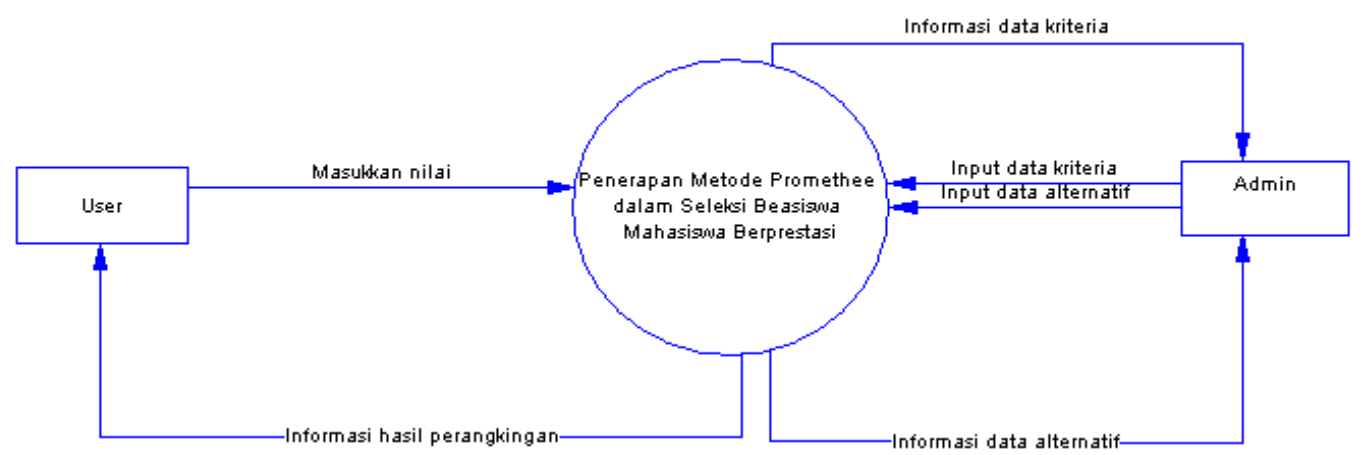

Gambar 8. Diagram Konteks

\section{Konsep Pembentukan Database}

Pembentukan database ini mempunyai empat tabel yaitu pro_admin, pro_nilai, pro_kriteria, pro_alternatif. Pada tabel pro_admin digunakan untuk menyimpan data username dan password.

\begin{tabular}{|c|c|c|c|c|c|c|}
\hline$\#$ & Name & Tyре & Collation Attributes & Null & Default & Extra \\
\hline 1 & id_admin & int(11) & & No & None & AUTO_INCREMENT \\
\hline 2 & nama & varchar(50) & & No & Mone & \\
\hline 3 & username & $\operatorname{varchar}(20)$ & & No & None & \\
\hline 4 & password & varchar(50) & & No & None & \\
\hline
\end{tabular}

Gambar 9. Struktur tabel pro_admin

Pada tabel pro_kriteria dan pro_altenatif digunakan untuk menyimpan datadata kriteria dan alternatif yang digunakan user nantinya, sedangkan tabel pro_nilai digunakan untuk menampung nilai perhitungan dari Promethee. 


\begin{tabular}{|c|c|c|c|c|c|c|}
\hline$\#$ & Name & Type & Collation Attributes & Null & Default & Extra \\
\hline 1 & id_kriteria & $\operatorname{int}(11)$ & & No & None & AUTO_INCREMENT \\
\hline 2 & nama & varchar(50) & & No & None & \\
\hline 3 & keterangan & text & & No & None & \\
\hline 4 & minmax & enum('min', 'max) & & No & None & \\
\hline 5 & tipe_preferensi & enum('1', '2', '3', '4', '5', '6') & & No & None & \\
\hline 6 & nilai_p & float & & No & None & \\
\hline 7 & nilai_q & float & & No & None & \\
\hline 8 & nilai_gausian & float & & No & None & \\
\hline
\end{tabular}

Gambar 10. Struktur tabel pro_kriteria

\begin{tabular}{|lllll} 
\# & Name & Type & Collation Attributes & Null Default Extra \\
1 & id_alternatif & int(11) & No None AUTO_INCREMENT \\
\hline 2 & nama & varchar $(50)$ & No None \\
\hline 3 & keterangan & text & No None
\end{tabular}

Gambar 11. Struktur tabel pro_alternatif

\begin{tabular}{|c|c|c|c|c|c|c|}
\hline$\#$ & Name & Type & Collation Attributes & Null & Default & Extra \\
\hline 1 & id_nilai & $\operatorname{int}(11)$ & & No & None & AUTO_INCREMENT \\
\hline 2 & id_alternatif & $\operatorname{int}(11)$ & & No & None & \\
\hline 3 & id_kriteria & $\operatorname{int}(11)$ & & No & None & \\
\hline 4 & nilai & float & & No & None & \\
\hline 5 & id_session & varchar(50) & & No & None & \\
\hline
\end{tabular}

Gambar 12. Struktur tabel pro_nilai

\section{Hasil Penelitian dan Pembahasan}

Bab ini merupakan hasil dan pembahasan sistem penerapan metode Promethee dalam menentukan mahasiswa yang berhak menerima beasiswa.

\section{Antar Muka Pengguna}

Antar muka pengguna digunakan untuk memudahkan user dalam melakukan operasi perhitungan. Pada antar muka ini akan dijabarkan di beberapa bagian yang akan digunakan oleh user dan admin.

\subsection{Halaman Utama}

Pada halaman utama terdapat juga menu input nilai dimana user dapat menginputkan nilai alternatif yang telah ditentukan oleh admin. Selain itu juga terdapat login admin dimana admin dapat memberikan data alternatif, data kriteria dan ubah password. 


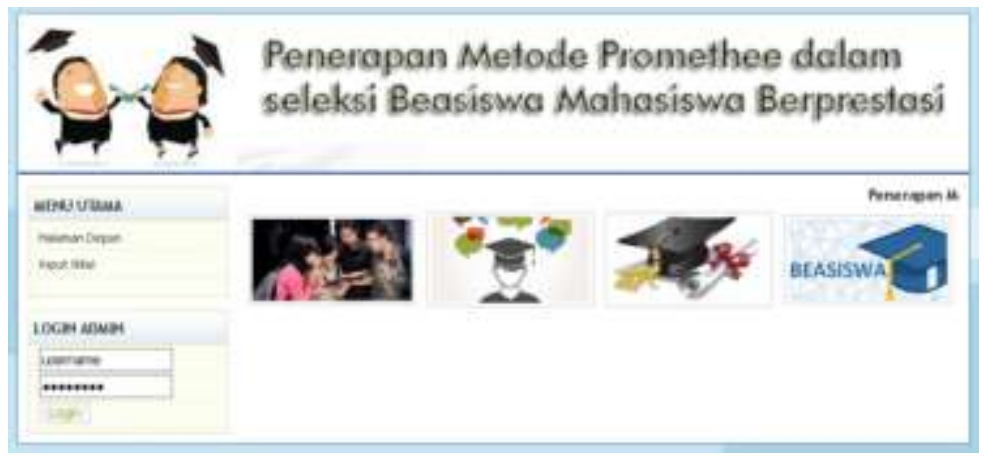

Gambar 13. Antarmuka Halaman Utama

\subsection{Halaman Perhitungan}

Pada input nilai berfungsi untuk memasukkan nilai untuk masing-masing alternatif berdasarkan kriteria. Setelah user memasukkan nilai akan tampil hasil perhitungan seperti pada Gambar 14.

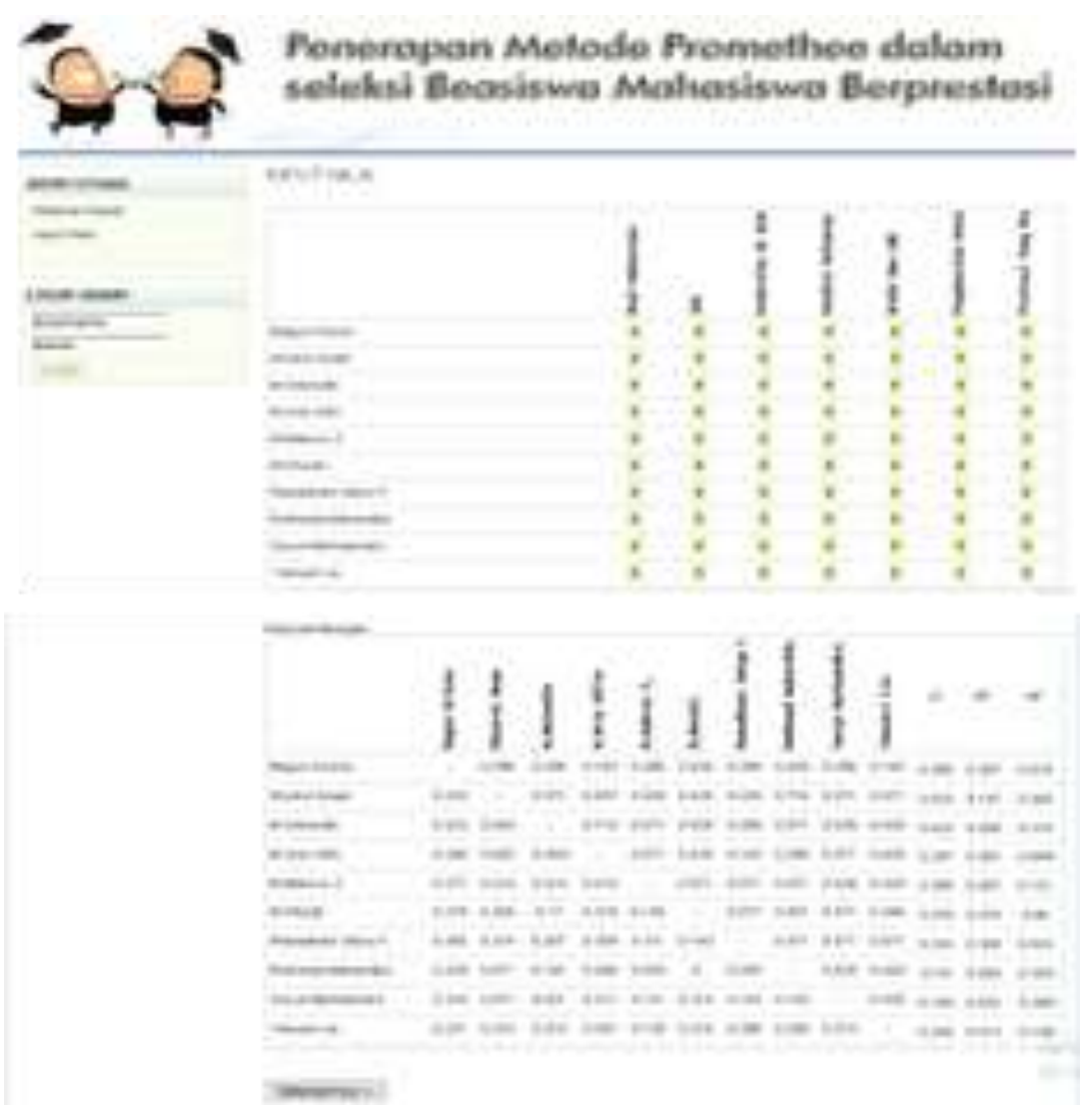

Gambar 14. Halaman Perhitungan

Pada halaman ini belum menampilkan hasil sistem pengambilan keputusan. Terdapat tombol "selanjutnya" untuk melanjutkan perhitungan dan menampilkan hasil akhir berupa rangking. 


\subsection{Halaman Perangkingan}

Pada halaman hasil rangking adalah halaman yang menampilkan hasil rangking dari perhitungan user. Pada halaman hasil rangking terdapat kesimpulan dari perhitungan user.

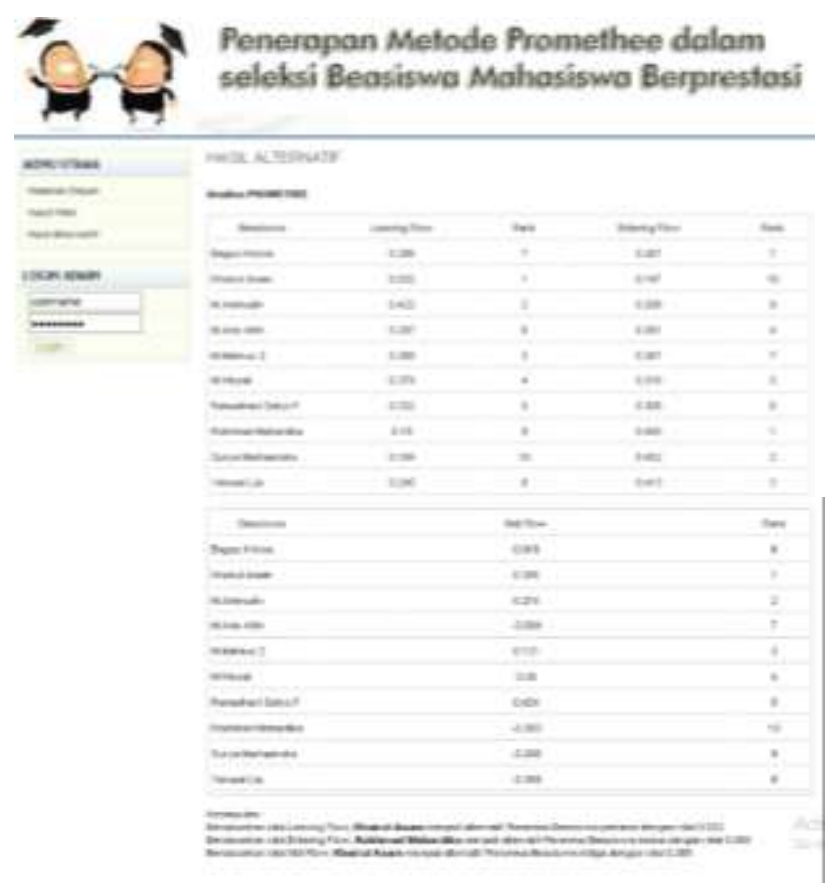

Gambar 15. Halaman Ranking

\subsection{Halaman Utama Admin}

Pada halaman admin ini digunakan oleh admin untuk mengatur data-data yang akan diinputkan oleh user. Pada halaman menu admin terdapat data alternatif, data kriteria, dan ganti password.

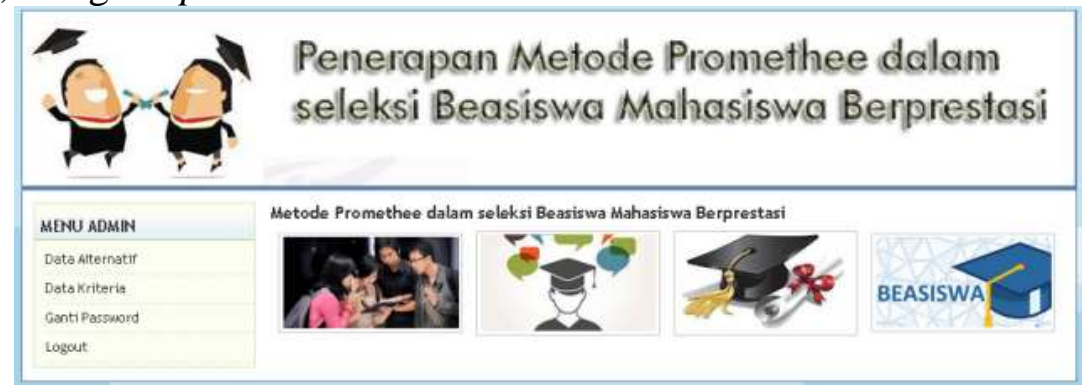

Gambar 16. Halaman Utama Admin

\subsection{Halaman Data Alternatif}

Pada halaman data alternatif admin dapat menambah, menghapus dan mengubah data-data alternatif. 


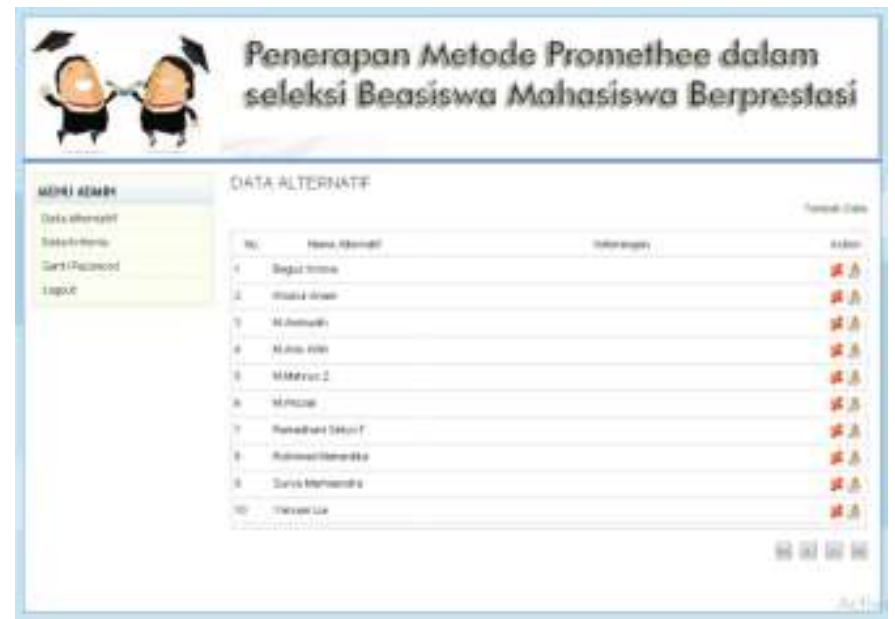

Gambar 17. Halaman Data Alternatif

Pada halaman ini terdapat menu tambah data, dimana menu tambah data admin dapat menambahkan data alternatif.

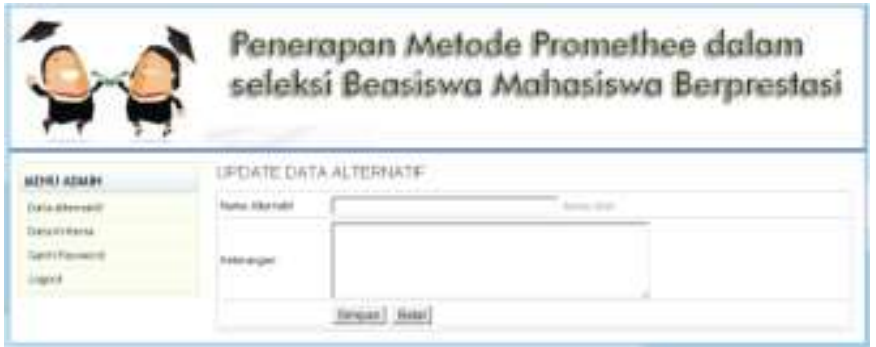

Gambar 18. Halaman Tambah Data Alternatif

\subsection{Halaman Data Kriteria}

Pada halaman data kriteria admin dapat menambah, menghapus dan mengubah data-data kriteria.

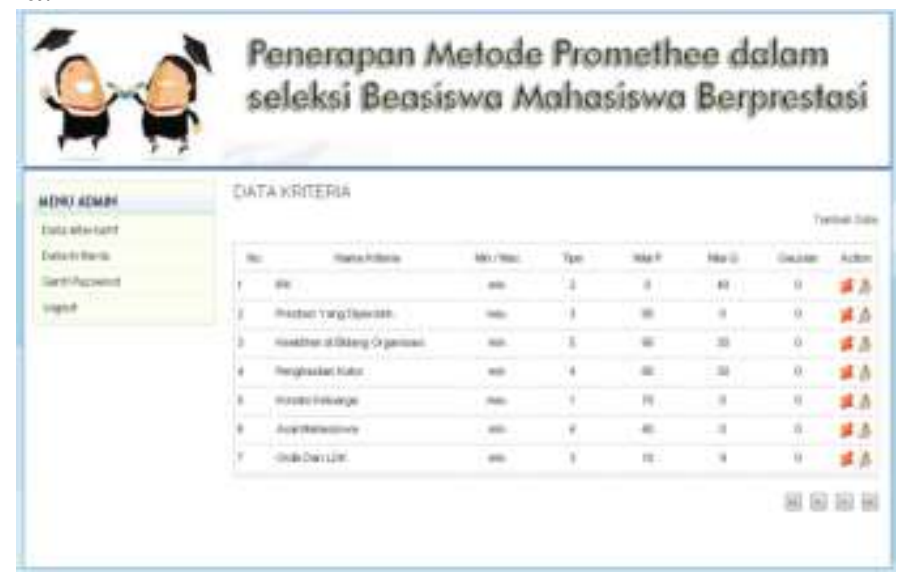

Gambar 19. Halaman Data Kriteria

Pada halaman ini terdapat menu tambah data, dimana menu ini digunakan admin untuk mengatur aturan perhitungan menggunakan metode Promethee. 


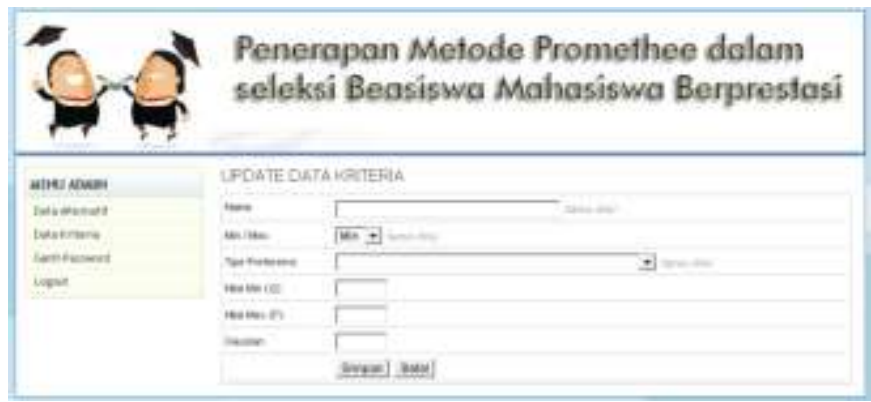

Gambar 20. Halaman Tambah Data Kriteria

Pada halaman ini admin dapat mengatur aturan-aturan yang nantinya digunakan untuk perhitungan Promethee.

\subsection{Halaman Ganti Password}

Pada halaman ganti password admin dapat merubah password admin. Untuk merubah password admin terlebih dahulu menginputkan password lama. Setelah password lama diinputkan admin menginputkan password baru dan diinput kembali password baru.

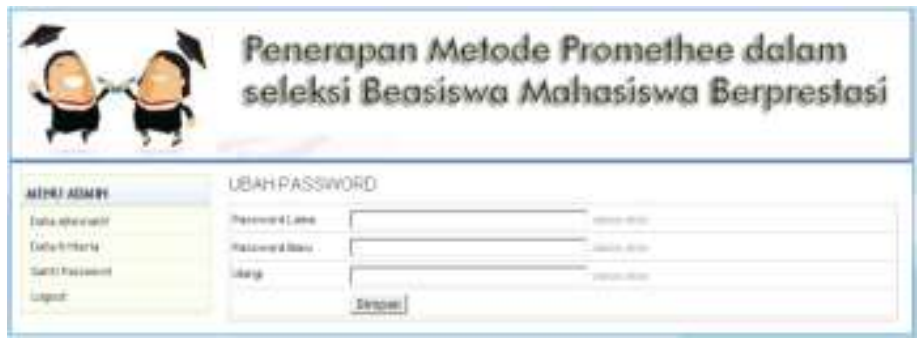

Gambar 21. Halaman Ganti Password

\section{Pengujian}

Untuk mendapatkan hasil yang maksimal maka perlu adanya pengujian pada sisi aplikasi. Pada halaman awal user memasukkan nilai untuk masing-masing kriteria tiap alternatif.

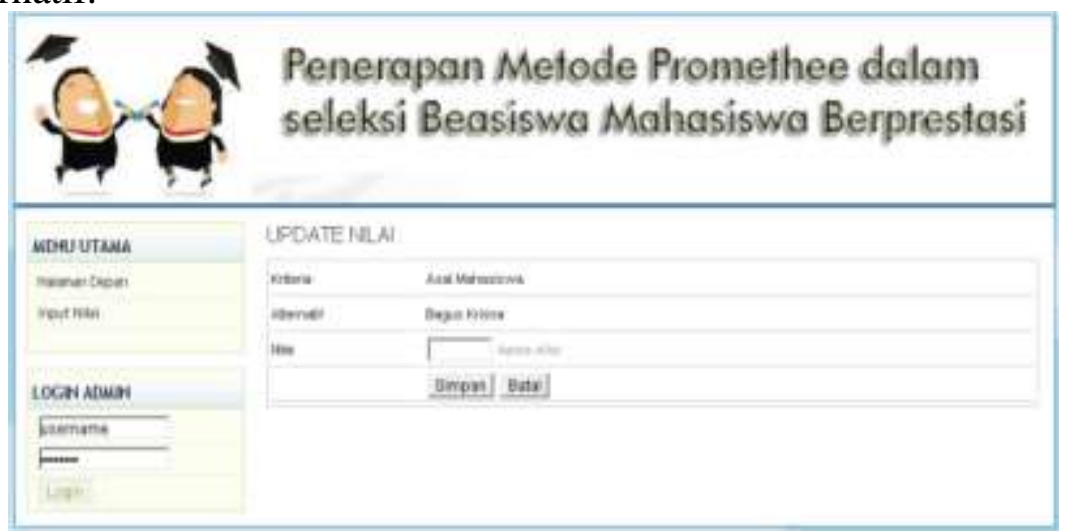

Gambar 22. Halaman Input Nilai 
Jika user telah memasukkan nilai maka akan tampil seperti pada Gambar 23. Selain menampilkan nilai-nilai yang telah dimasukkan oleh user, terdapat hasil perhitungan LF(Leaving Flow), EF (Entering Flow), dan $\mathrm{NF}($ Net Flow). Untuk melihat hasil akhir dari perhitungan maka user melakukan langkah berikutnya yaitu dengan menekan tombol selanjutnya.

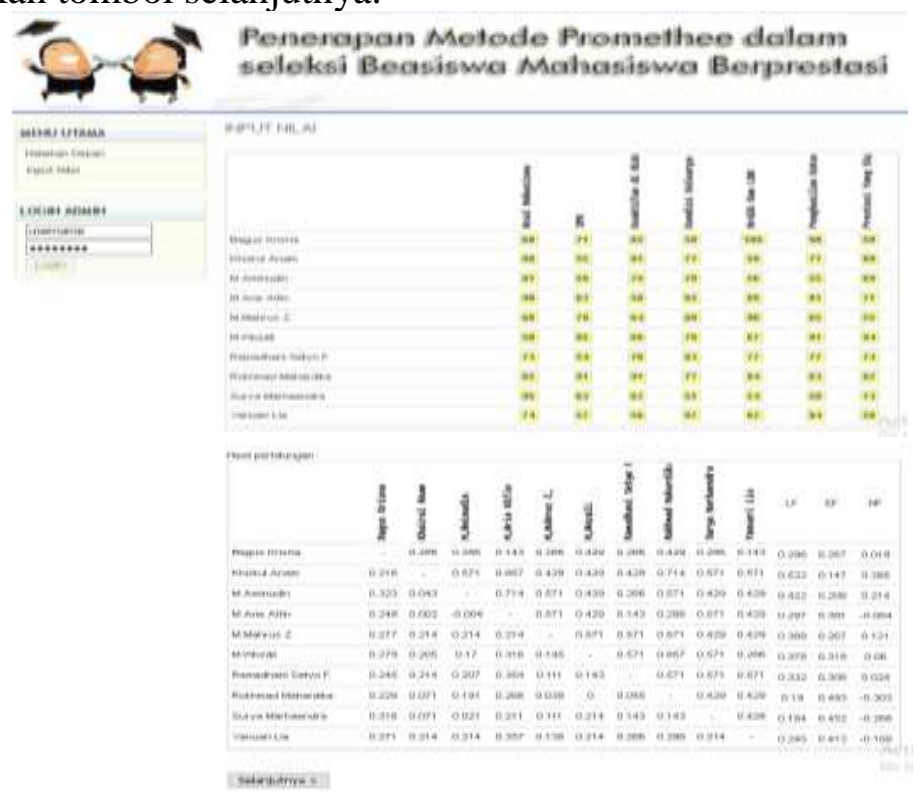

\section{Gambar 23. Halaman Setelah User Memasukkan Nilai}

Pada halaman akhir user dapat mengetahui hasil akhir perangkingan berdasarkan masukkan user. Pada hal ini studi kasusnya adalah menentukan mahasiswa yang berhak menerima beasiswa. Kriteria-kriteria untuk menentukan penerima beasiswa adalah asal mahasiswa, nilai IPK, keaktifan di bidang organisasi, kondisi keluarga, ordik \& LDK, penghasilan kotor orangtua, prestasi yang diperoleh non akademik. Pada halaman akhir terdapat kesimpulan yaitu berdasarkan nilai LF(Leaving Flow), EF (Entering Flow), dan NF(Net Flow), sehingga user dapat memilih user mana yang akan diprioritas mendapatkan beasiswa berdasarkan dari kesimpulan yang ada.

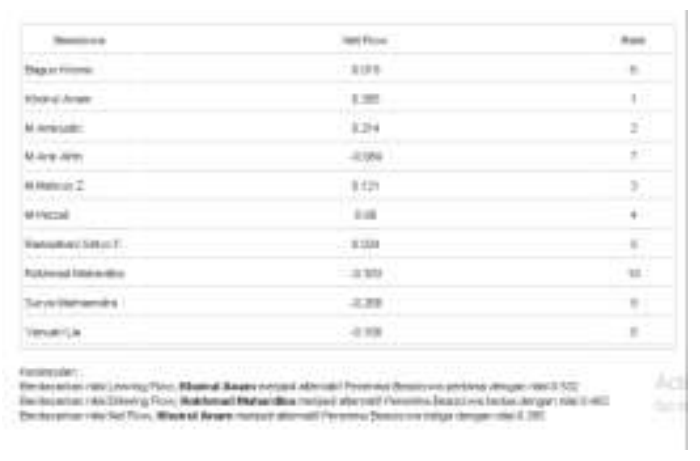

Gambar 24. Halaman Hasil Akhir 


\section{KESIMPULAN DAN SARAN}

\section{a. Kesimpulan}

Setelah dilakukan pengujian terhadap sistem yang telah dibuat, dapat disimpulkan bahwa:

1. Sistem penunjang keputusan menggunakan metode Promethee dapat membantu memberikan hasil rekomendasi mahasiswa yang berhak menerima beasiswa sesuai dengan pertimbangan kriteria yang digunakan

2. Sistem dapat membantu user dalam mengambil keputusan untuk menentukan mahasiswa penerima beasiswa yang tepat.

\section{b. Saran}

Analisa penentuan keputusan ini hanya menggunakan satu metode, yaitu metode Promethee sehingga tidak dapat di bandingkan tingkat efektifitas dan efisiensi dengan metode yang lain. Sehingga untuk mengetahui perbedaan dengan metode lain, pada penelitian selanjutnya perlu menambahkan metode yang berbeda untuk dapat melihat perbedaan atau persamaan hasil analisa dengan data yang sama.

\section{Daftar Pustaka}

Kadarsah, Suryadi, Ali M, Ramdhani. (2002). Sistem Pendukung Keputusan. Bandung: PT Remaja Rosdakarya.

Lemantara, Julianto, dkk. "Rancang Bangun Sistem Pendukung Keputusan Pemilihan Mahasiswa Berprestasi Menggunakan Metode AHP dan Promethee". JNTETI, Vol. 2, No. 4, Februari 2013.

Sanada, H, MT Wahyudin, H Sutarno, "Rancang Bangun Sistem Pendukung Keputusan Seleksi Penerimaan Siswa Baru Dengan Menggunakan Metode AHP Dan PROMETHEE di SMA.”, Jurnal Ilmu Komputer (JIK), 2013 fpmipa.upi.edu

Turban, Efraim, Jay E.Aronson, dan Ting Peng Liang (2005). Decision Support Systems and Intelligent Systems (Sistem Pendukung Keputusan dan Sistem Cerdas) edisi ketujuh jilid 1. Yogjakarta : Andi Offset.

Yuwono, Bambang, dkk. "Sistem Pendukung Keputusan Menggunakan Metode Promethee (Studi Kasus : Stasiun Pengisian Bahan Bakar Umum)". Jurnal TELEMATIKA Vol. 8, No. 1, JULI $2011: 63-74$. 